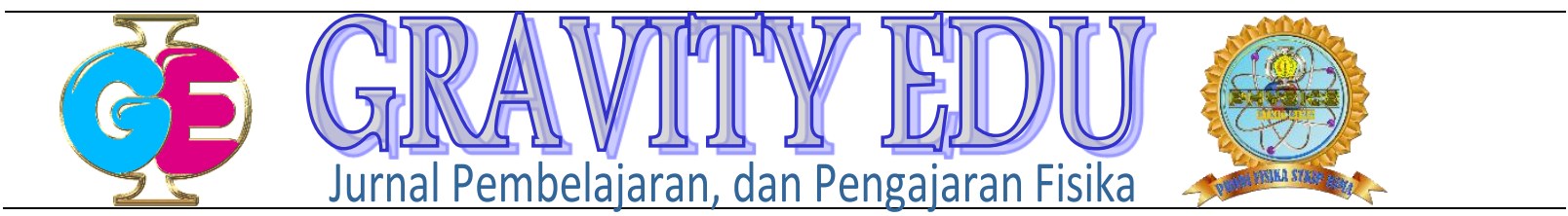

\title{
Implementasi Model CLIS Untuk Meningkatkan Hasil Belajar Siswa Pada Materi Suhu dan Perubahannya
}

Indriyani Bidara Kansil ${ }^{1)}$, Dewi Diana Paramata ${ }^{2)}$, Tirtawaty Abdjul ${ }^{3)}$

Jurusan Fisika Universitas Negeri Gorontalo

Email : indribidara@gmail.com, dianaparamata662@gmail.com, tirtaabjul@gmail.com

\begin{abstract}
ABSTRAK : Penelitian ini bertujuan untuk meningkatkan hasil belajar siswa pada materi suhu dan perubahannya melalui implementasi model pembelajaran children learning in science. Jenis penelitian adalah penelitian tindakan kelas model Kemis dan Taggart dengan menggunakan dua siklus, setiap siklus yang terdiri dari: perencanaan, pelaksanaan, pengamatan, dan refleksi .Siswa yang dikenai tindakan adalah siswa kelas VII ${ }^{\mathrm{B}}$ SMP Negeri 5 Gorontalo, tahun ajaran 2019/2020 dengan jumlah 30 orang. Hasil penelitian menunjukan bahwa implementasi model children learning in science dapat meningkatkan hasil belajar siswa, yaitu pada siklus I persentase ketuntasan belajar masih rendah dan mengalami peningkatan pada siklus II . Untuk aktivitas guru jumlah nilai setiap aspek yang diperoleh pada siklus I yaitu 76, 7\%, dan mengalami peningkatan pada siklus II mencapai $83,4 \%$, aspek aktivitas siswa pada siklus I dengan persentase $9,67 \%$ sedangkan pada siklus II meningkat dengan persentase $9,81 \%$, dan hasil belajar siswa dengan persentase yang mengalami peningkatan pada siklus siklus I dan II yaitu dari 66,6\% menjadi $96 \%$. Berdasarkan hal tersebut dapat disimpulkan bahwa implementasi model children learning in science dapat meningkatkan hasil belajar siswa.
\end{abstract}

Kata kunci: Model Children Learning In Science (CLIS), dan Hasil Belajar Siswa.

\section{ABSTRACT}

This study aims to improve students learning outcomes in temperature and its change material thought the implementation of children learning in science model. This research is a classroom action research using Kemmis and Taggart model with two cycles, and each cycle consists of planning, implementation, observation, and reflection. The subjects of this research are students in grade VII ${ }^{\mathrm{B}}$ of SMP Negeri 5 Kota Gorontalo in the 2019/2020 academic year consist of 30 student. The result shows that the implementation of children learning in science model can improve students learning outcomes, which in cycle 1 the percentage of learning completeness is still low and has increased cycle II. For the teacher activity, the total value in every aspect obtained in cycle I is $76,7 \%$ and increased in cycle II to $83,4 \%$, aspect of students activity in cycle I with the percentage of $9,67 \%$ whereas in cycle II has increased to $9,81 \%$, and the percentage of student learning outcomes has increased in cycle I and cycle II which is from $66,6 \%$ to $96 \%$. For the reasons , it can be concluded that the implementation of children learning in science model is able to improve students learning outcomes.

\section{PENDAHULUAN}

Pendidikan adalah suatu usaha sadar dan terencana untuk mewujudkan suasana belajar dan proses pembelajaran agar peserta didik dapat aktif mengembangkan potensinya. Sekolah merupakan lembaga formal yang berfungsi membantu khususnya orang tua dalam memberikan formal pendidikan kepada anak-anak mereka. Pendidikan merupakan pengetahuan, keterampilan, dan sikap kepada anak didiknya secara lengkap sesuai dengan yang mereka butuhkan. Pemerintah telah menetapkan Undang-undang Nomor 20 Tahun 2003 tentang Sistem Pendidikan Nasional (SPN). Dalam UU tersebut SPN terdapat beberapa potensi akademik yang akan dikembangkan, dimana potensi tersebut berkaitan dengan karakter. Hal tersebut dijabarkan dalam pasal 3 UU SPN bahwa "Pendidikan nasional berfungsi mengembangkan kemampuan dan pembentukan watak serta peradaban bangsa yang bermartabat dalam rangka mencerdaskan kehidupan bangsa, bertujuan untuk berkembangnya potensi peserta didik agar menjadi manusia yang beriman dan bertakwa kepada Tuhan Yang Maha Esa, berakhlak mulia, sehat, berilmu, cakap, dan kreatif, mandiri, dan menjadi negara yang demokratis serta bertanggung jawab." [1]

Menurut Depdiknas (2006), mata pelajaran IPA merupakan mata pelajaran yang sulit dipahami karena banyak rumus matematis dan perhitungan dalam penyelasaian soal-soal didalamnya. Mata pelajaran IPA 
adalah pengetahuan yang diperoleh melalui pengumpulan data dengan eksperimen, pengamatan, dan deduksi untuk menghasilkan suatu penjelasan tentang gejala alam yang dapat dipercaya.[2]

Keterlibatan siswa dalam kegiatan belajar mengajar merupakan aspek penting dalam proses pembelajaran, dengan melibatkan diri dalam kegiatan belajar mengajar, siswa akan lebih berinteraksi secara aktif dalam pembelajaran, sehingga lebih memudahkan siswa menguasai materi yang diajarkan. Penguasaan siswa pada materi tentu saja akan berdampak pada peningkatan hasil belajar, dalam hal ini siswa akan mencapai ketuntasan belajar. Untuk mencapai ketuntasan belajar maka siswa harus memenuhi nilai ketuntasan pada mata pelajaran IPA sesuai dengan Kriteria Ketuntasan Minimal (KKM) yaitu 75.[3]

Kenyataan di lapangan menunjukan bahwa hasil belajar pelajaran IPA di SMP Negeri 5 Kota Gorontalo lebih khusus pada materi suhu dan perubahannya sangat rendah. Hal ini di dukung dengan kegiatan Program Pengalaman Lapangan (PPL) pada tahun ajaran 2018/2019 yang terbukti bahwa hasil belajar siswa pada materi ini tidak sesuai dengan yang diharapkan. Nilai rata-rata hasil belajar seluruh siswa kelas VII-B pada tahun ajaran 2018/2019 semester ganjil adalah 50,31.

Kesulitan siswa dalam mempelajari IPA terjadi karena pelajaran itu sangat tergantung bagaimana cara guru mengajarkan mata pelajaran yang bersangkutan kepada siswa. Guru sebaiknya dapat mengubah rasa takut anak terhadap pelajaran IPA menjadi senang dapat membangkitkan minat dan keaktifan siswa dalam mengikuti pelajaran. Banyak cara bagi seorang guru untuk menyampaikan materi pelajaran yang dapat membuat siswa merasa senang, diantaranya dengan mengggunakan model dalam pembelajaran. Salah satu model pembelajaran yang di pakai adalah model pembelajaran Children Learning In Science ( CLIS).

Model CLIS adalah salah satu model pembelajaran yang menggunakan pendekatan kontruktivisme. Tyler (dalam Bektisarso, 2000: 742) menyatakan bahwa model CLIS lebih menekankan pada kegiatan siswa untuk menyempurnakan proses pencapaian dalam mendapatkan ide-ide, menyesuaikan dengan ilmu pengetahuan yang ada, memecahakan dan mendiskusikan masalah-masalah yang dapat muncul, sehingga siswa dapat mengemukakan pendapatnya sendiri, sebelum guru memberikan penyempurnaan ide-ide ilmiah, siswa dituntun menuju pembangunan ide baru atau ide yang lebih ilmiah.[4]

Menurut Handayani, dkk (2004 : 39), bahwa: kelebihan-kelebihan model pembelajaran CLIS adalah sebagai berikut : (1) Gagasan anak lebih mudah untuk dimunculkan; (2) Membiasakan siswa untuk belajar mandiri dalam memecahkan suatu masalah; (3) Empat syarat perubahan konsepsi yang dikemukakan oleh posner et al terpenuhi; (4) Menciptakan kreatifitas siswa untuk belajar sehingga tercipta suasana kelas yang lebih nyaman dan kreatif, terjadi kerjasama sesama siswa dan siswa terlibat langsung dalam melakukan kegiatan; (5) Menciptakan belajar yang lebih bermakna karena timbulnya kebanggan siswa menemukan sendiri konsep ilmiah yang dipelajari; (6) Guru mengajar akan lebih efektif karena dapat menciptakan suasana belajar yang akan aktif dan menyenangkan.[4]

Hal ini didukung oleh penelitian sebelumnya oleh Rustaman N, yang berpendapat bahwa, penerapan model pembelajaran Children Learning in Science dapat meningkatkan hasil prestasi belajar pada mata pelajaran IPA. Sasaran penelitian Rustaman N, adalah siswa kelas X5 SMA Negeri 3 Malang. Dari penelitian tersebut Rustaman N menyimpulkan bahwa ; penerapan model pembelajaran Children Learning In Science (CLIS) berbantuan SwisHmax juga terbukti dapat meningkatkan keterampilan proses sains siswa. [5]

\section{METODE PENELITIAN}

Penelitian tindakan kelas ini terdiri atas empat tahap yaitu perencanaan tindakan (plan), pelaksanaan tindakan (action), pengamatan (observe), serta dilakukan refleksi (reflect), dengan model penelitian yang digunakan adalah model penelitian kelas Kemmis dan Mc Taggart Model Kemmis dan Taggart (Kusumah dan Dwigatama, 2012: 2021).[6]

Penelitian ini dilaksanakan di SMP Negeri 5 Kota Gorontalo yang berlokasi di di Jalan Sultan Hasanudin No. 22 Kecamatan Kota Selatan, Kota Gorontalo. Subjek penelitian ini adalah siswa kelas VII-B, tahun pelajaran 2019/2020, dengan jumlah siswa 30 orang .

Dalam proses penelitian tindakan kelas analisis data merupakan hal yang utama untuk mendapatkan data dari hasil yang akurat, daalam analisis data diharapkan dalam dilakukan secara bertahap pada akhir siklus yang digunakan pada penelitian ini. Adapun data yang dianalisis meliputi data hasil pengamatan aktivitas guru, aktivitas siswa, dan tes hasil belajar dengan teknik analisis data diuraikan sebagai berikut:

1. Hasil Belajar

Untuk mengetahui hal tersebut di atas, maka digunakan rumus sebagai berikut:

a. Ketuntasan Perorangan

$$
\%=\frac{\text { Jumlah skoryangdiperoleh }}{\text { Jumlah skor total }} x 100 \%
$$

b. Ketuntasan Klasikal 


$$
\%=\frac{\text { Jumlah skoryangdiperoleh }}{\text { Jumlah skor total }} x 100 \%
$$

c. Nilai rata-rata

$$
\%=\frac{\text { Jumlah skory angdiperoleh }}{\text { Jumlah skor total }} \times 100 \%
$$

\section{Data Pengamatan Aktivitas Siswa}

Seluruh data hasil pengamatan aktivitas siswa dianalisis secara kauntitatif dengan menggunakan presentase kegiatan aktivitas siswa selama kegiatan belajar mengajar berlangsung. Untuk persentase keberhasilan digunakan rumus :

$\%=\frac{\text { Jumlah skoryangdiperoleh }}{\text { Jumlah skor total }} x 100 \%$

\section{Data Pengamatan Aktivitas Guru}

Data hasil observasi kegiatan guru dianalisis dengan menggunakan persentase aktivitas guru selama kegiatan belajar mengajar berlangsung. Untuk persentase keberhasilan digunakan rumus :

$\%=\frac{\text { Jumlah skoryangdiperoleh }}{\text { Jumlah skor total }} \times 100 \%$

(Purwanto, $2011: 102)$ (7)

\section{HASIL DAN PEMBAHASAN}

Implementasi model pembelajaran children learning in science terbukti dapat meningkatkan hasil belajar berdasarkan penelitian sebelumnya.Tujuan dari penelitian adalah untuk memperbaiki kegiatan pelaksanaan pembelajaran dengan evaluasi kognitif melalui tes hasil belajar yang diberikan kepada peserta didik sebanyak 30 peserta didik pada mata pelajaran Ilmu Pengetahuan Alam (IPA). Hasil yang diperoleh dari siklus pertama dan kedua sebagaimana diuraikan berikut ini :

\section{A. Siklus I}

\section{Aktivitas guru dalam pembelajaran}

Pengamatan yang dilakukan selama kegiatan pembelajaran yang dilakukan oleh guru sebagai peneliti menggunakan instrumen penelitian lembar pengamatan aktivitas guru. Sebanyak 13 aspek pengamatan dalam isntrumen tersebut yaitu: a). Kegiatan pendahuluan meliputi; memberikan apersepsi, memotivasi siswa dengan mengajukan pertanyaan, menyampaikan tujuan pembelajaran yang akan dicapai, serta menginformasikan sintaks model pembelajaran yang akan diterapkan; b). Kegiatan inti meliputi; memberikan penjelasan materi, menanyakan hal-hal yang belum dipahami, mengajukan pertanyaan untuk memunculkan gagasan siswa tentang materi, membimbing masing- masing kelompok belajar dalam menyelesaikan LKPD, serta memberikan penjelasan materi; c), Kegiatan penutup meliputi; membimbing siswa dalam membuat kesimpulan, memberikan tugas rumah, memberikan penguatan kepada kelompok yang memilki kinerja yang baik, serta refleksi proses pembelajaran. Pengamatan dilakukan oleh tiga orang pengamat selama kegiatan pembelajaran berlangsung dalam siklus pertama 2 kali jam pelajaran. Hasil yang diperoleh dari pengamatan selama kegiatan pembelajaran berlangsung sebagaimana terdapat dalam gambar 1.1 berikut.

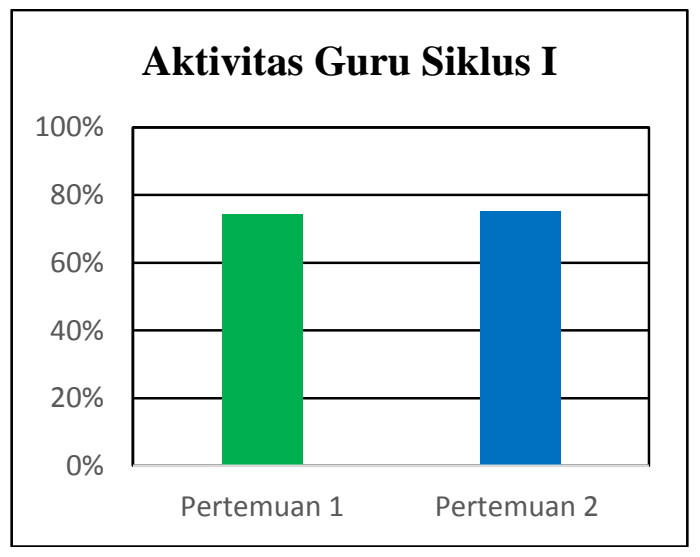

Gambar 1.1 Diagram Aktivitas Guru Siklus I

Dari diagram di atas menunjukan capaian persentase setiap aspek pengamatan untuk masingmasing pertemuan pertama dan kedua selama siklus I berlangsung. Terdapat beberapa aspek yang telah diperbaiki sehingga capaian pada pertemuan satu dan dua mencapai $74,2, \%$ dan $75,1 \%$.

2. Aktivitas siswa dalam pembelajaran

Aktivitas peserta didik selama siklus pertama berlangsung diamati oleh 3 orang pengamat. Pengamat tersebut menggunakan instrumen berupa lembar pengamatan aktivitas peserta didik pertemuan pertama dan pertemuan kedua dalam siklus I. Instrumen yang digunakan memuat 12 item aspek pengamatan yang terdiri dari: a). Kegiatan pendahuluan meliputi; kesiapan siswa dalam pembelajaran, motivasi dalam pembelajaran, menyimak tujuan pembelajaran yang akan dicapai, dan memahami langkah-langkah model pembelajaran yang diterapkan; b). Kegiatan inti meliputi; mengorganisasikan dalam kelompok belajar, menerima penjelasan materi pembelajaran, menanyakan materi yang belum dipahami, mengajukan ide/ gagasan materi pembelajaran, mengerjakan tugas /LKPD, dan mempresentasikan 
hasil diskusi kelompok; c).Kegiatan penutup meliputi ; membuat kesimpulan dari materi yang diajarkan, dan refleksi proses pembelajaran.yang diamati selama kegiatan pembelajaran berlangsung dengan model pembelajaran. Setiap pengamat, mengamati aktivitas peserta didik sebanyak 10 peserta didik yang diamati. Pengamatan yang dilakukan oleh pengamat aktivitas peserta didik di gambarkan dalam diagram1.2 berikut.

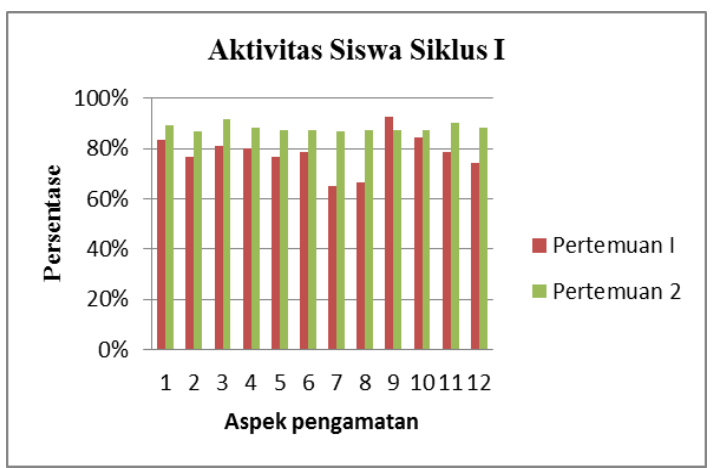

Gambar 1.2 Diagram Aktivitas Siswa Siklus I

Diagram di atas menunjukan aktivitas peserta didik selama siklus I berlangsung untuk pertemuan pertama dan kedua yaitu dengan persentase $9,03 \%$ pada pertemuan pertama dan meningkat menjadi 9,37\% pada pertemuan kedua.

\section{Hasil Belajar Siswa}

Akhir dari setiap siklus tentunya dilakukan evaluasi, guna mengetahui pencapaian selama pembelajaran yang telah digunakan sebelumnya. Peneliti melakukan evaluasi kognitif pada peserta didik sebanyak 30 orang peserta didik dengan materi suhu dan perubahan. Instrumen yang digunakan dalam pengkuran capaian pembelajaran peserta didik berupa tes hasil belajaryang memuat 10 butir soal dengan tingkatan taksonomi Bloom

\section{Persentase hasil belajar siklus I}

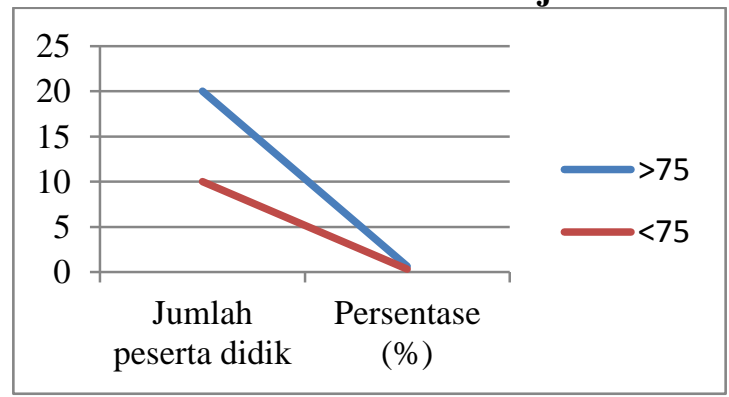

Gambar 1.3 Diagram Hasi Belajar Siklus I

Diagram di atas menunjukan hasil belajar siswaselama siklus I berlangsung dengan perolehan nilai $\geq 75$ persentase yang tuntas $66,6 \%$, dan nilai $\geq 75$ persentase yang tidak tuntas $33,33 \%$.

B. Siklus II

1. Aktivitas guru dalam pembelajaran

Pengamatan keterlaksanaan pembelajaran dilakukan sebagaimana pengamatan yang dilakukan pada siklus sebelumnya yaitu siklus I. Pengamatan ini dilakukan untuk mengetahui manifestasi dari model pembelajaran CLIS kedalam kegiatan belajar mengajar peneliti sebagai guru mata pelajaran pada materi suhu dan perubahannya. Pengamatan dilakukan dengan instrumen lembar observasi keterlaksanaan atau aktivitas guru, guna melihat kesesuaian yang telah dilakukan oleh guru dengan model pembelajaran yang implementasikan selama kegiatan pembelajaran berlangsung. Pengamatan dilakukan sebanyak 2 kali jam pelajaran dalam siklus II. Capaian setiap aspek pengamatan sebagaimana terdapat dalam diagram pada gambar 2.1 berikut ini.

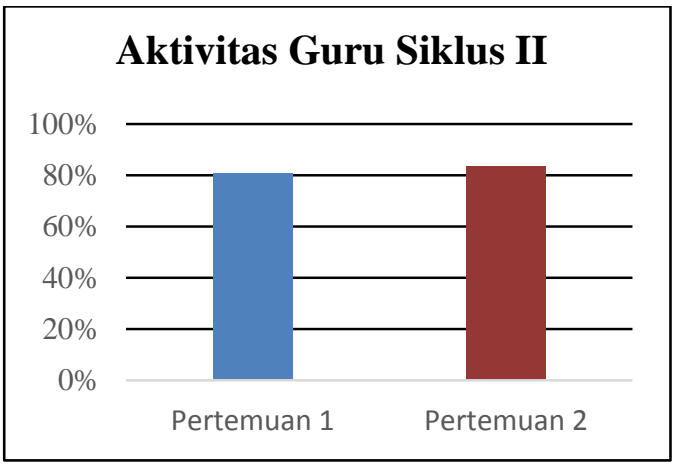

Gambar 2.1 Diagram Aktivitas Guru Siklus II

Dari diagram di atas menunjukan capaian persentase setiap aspek pengamatan untuk masingmasing pertemuan pertama dan kedua selama siklus II berlangsung. Terdapat beberapa aspek yang telah diperbaiki sehingga capaian pada pertemuan satu dan dua mencapai $80,7, \%$ dan $83,6 \%$.

2. Aktivitas Siswa

Pengamatan yang dilakukan untuk mengmati aktivitas peserta didik menggunakan instrumen lembar pengamatan aktivitas peserta didik. Sebanyak 30 peserta didik yang diamati oleh 3 orang pengamat masing-masing 10 orang peserta didik. Instrumen yang digunakan sebagaimana pada siklus Pertama yaitu siklus I. Persentase setiap aspek yang diamati sebagaimana ditunjukan dalam diagram pada gambar 2.2 berikut. 


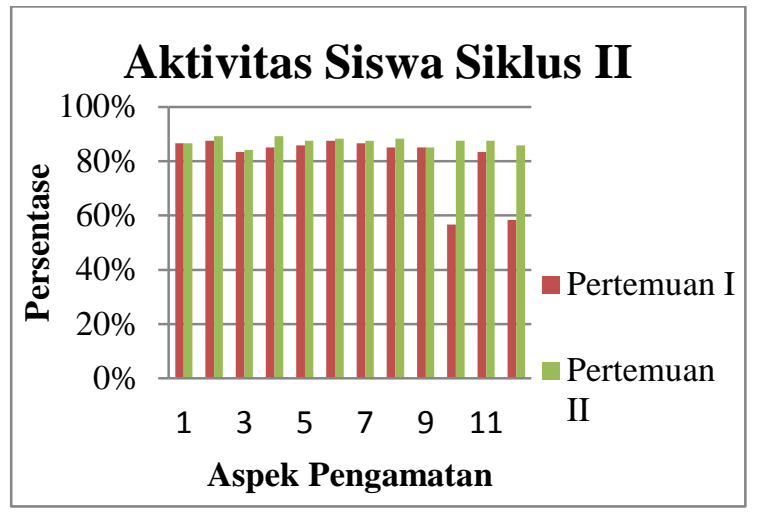

Gambar 2.2 Diagram aktivitas siswa siklus II

Diagram di atas menunjukan aktivitas peserta didik selama siklus II berlangsung untuk pertemuan pertama dan kedua yaitu dengan persentase $9,48 \%$ pada pertemuan pertama dan meningkat menjadi 9,98\% pada pertemuan kedua.

\section{Hasil Belajar Siswa}

Hasil belajar pada siklus II diperoleh sebagaimana pada siklus sebelumnya yaitu dengan menggunakan instrumen tes hasil belajar yang terdiri atas 10 butir soal uraian. Adapun ketuntasan hasil belajar siswa tersebut dapat dilihat dari pencapaian kognitif siswa yang berdasarkan pada tingkatan kognitif taksonomi Bloom. Berikut capaian persentase peserta didik yang mencapai standar ketuntasan minimal.

Persentase hasil belajar siklus II

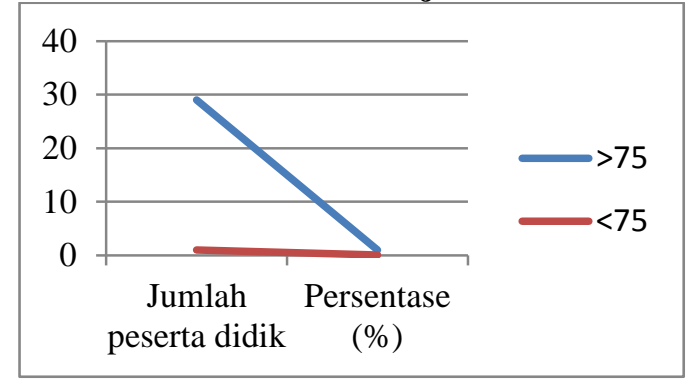

Gambar 2.3 Hasil Belajar Siklus II

Diagram di atas menunjukan hasil belajar siswa selama siklus I berlangsung dengan perolehan nilai $\geq 75$ persentase yang tuntas $96 \%$, dan nilai $\geq 75$ persentase yang tidak tuntas $3,3 \%$.

Hasil belajar adalah komponen penting dalam kegiatan pembelajaran untuk melihat keberhasilan siswa dalam kegiatan belajar yang telah dilaluinya. Capaian yang diperoleh untuk hasil belajar siklus I terdapat beberapa peserta didik yang tuntas dan belum tuntas,. sedangkan pada siklus II untuk hasil belajar siswa memiliki peningkatan ketuntasan belajar sangat jauh berbeda jika dibandingkan dengan ketuntasan hasil belajar pada siklus I. Yang berarti pada siklus keberhasilan pembelajaran terjadi pada siklus II karena adanya kemauan dari peserta didik hingga dapat menciptakan kemajuan atau kenaikan pada hasil belajar. Hal ini sejalan dengan pendapat Hamalik (2006), memberikan gambaran bahwa hasil belajar yang diperoleh dapat diukur melalui kemajuan yang diperoleh siswa setelah belajar dengan sungguh-sungguh. Hasil belajar tampak terjadinya perubahan tingkah laku pada diri siswa yang dapat diamati dan diukur melalui perubahan sikap dan keterampilan. Perubahan tersebut dapat diartikan terjadinya peningkatan dan pengembangan yang lebih baik dibandingkan dengan sebelumnya.

Hasil belajar merupakan hasil dari suatu interaksi tindak belajar dan tindak mengajar. Dari sisi guru, tindak mengajar diakhiri dengan proses evaluasi hasil belajar. Sedangkan dari sisi siswa, hasil belajar merupakan berakhirnya pengalaman dan puncak proses belajar. (Dimyati 2006: 3), oleh karena itu hasil belajar adalah hasil akhir dalam proses kegiatan pembelajaran yang diantaranya terdapat aktivitas guru dan aktivitas siswa .(8)

Aktivitas guru merupakan bagian yang paling penting pembelajaran. Dalam penelitian ini, aktivitas guru sebagai peneliti, dilakukan pengamatan dengan menggunakan instrumen lembar pengamatan. Kegiatan belajar mengajar yang perlu diperhatikan guru adalah skenario proses pembelajaran , memulai saat membuka dan menutup pembelajaran, memperhatikan sintaks model pembelajaran yang akan digunakan, keterampilan membimbing kelompok belajar dan sebagainya. Hal ini sesuai dengan pendapat Mukminan (2013), yang menyatakan bahwa keterampilan dasar mengajar adalah kecakapan atau kemampuan pengajar dalam menjelaskan konsep terkait dengan materi pembelajaran. Dengan demikian seorang pengajar harus mempunyai persiapan mengajar, antara lain harus menguasai bahan pembelajaran mampu memilih strategi, metode dan media, penguasaan kelas yang baik, serta menentukan sistem penilaian yang tepat .[9]

Aktivitas guru dalam pembelajaran tidak akan terlaksana tanpa adanya keterlibatan siswa yang mendukung dalam proses pembelajaran, aktivitas siswa adalah hal yang perlut diperhatikan dalam pembelajaran, hal ini dapat dilihat dari peningkatan dari siklus pertama dan kedua yang perlu diperhatikan adalah pada saat siswa sulit menjawab apersepsi, sulit dalam menyimpulkan materi, bahkan sulit dalam berinteraksi dalam kelompok belajar (melakukan percobaan, dan menganalisis hasil percobaan lewat pertanyaan-pertanyan yang ada dalam LKPD). Hal ini sesuuai dengan pendapat Wahyuningsih dan Murwani (2015) yang mengatakan bahwa aktivitas belajar siswa adalah unsur dasar yang penting bagi keberhasilan proses pembelajaran. Melalui aktivitas, siswa akan dapat memahami pelajaran dari pengalamannya sehingga akan mempertinggi hasil belajarnya.[10]. 


\section{KESIMPULAN}

Dari uraian analisis hasil penelitian dan pembahasan dari penelitian ini, pelaksanaan pembelajaran siklus I dan siklus II masing-masing menggunakan model pembelajaran CLIS dengan materi pembelajaran suhu dan perubahannya. Hal ini dilihat dari pencapaian hasil belajar yang dinilai melalui aktivitas guru aktivitas siswa, dan hasil belajar siswa pada kedua siklus yang berbeda yaitu sebagai berikut : Hasil penelitian menunjukan bahwa mengimplementasikan model children learning in science hasil belajar siswa dapat meningkat, yaitu pada siklus I persentase ketuntasan belajar masih rendah dan mengalami peningkatan pada siklus II : 1) Untuk aktivitas guru jumlah nilai setiap aspek yang diperoleh pada siklus I yaitu $76,7 \%$, dan mengalami peningkatan pada siklus II mencapai $83,4 \%$ 2) aspek aktivitas siswa pada siklus I dengan persentase 9, 67\% sedangkan pada siklus II meningkat dengan persentase $9,81 \%$. 3) hasil belajar siswa dengan persentase yang mengalami peningkatan pada siklus siklus I dan II yaitu dari $66,6 \%$ menjadi $96 \%$.Hal ini menunjukan bahwa implementasi model pembelajaran Children Learning in Science (CLIS) dapat meningkatkan hasil belajar peserta didik pada materi suhu dan perubahannya.

\section{DAFTAR PUSTAKA}

[1]. Depdiknas. 2006. Kurikulum Tingkat Satuan Pendidikan: Standar Kompotensi dan Kompotensi Dasar Mata Pelajaran IPA SMP/MTs. Jakarta : Balitbang Depdiknas.

[2]. Depdiknas, 2007. Model-Model Pembelajaran Matematika dan IPA. Jakarta : Depdiknas.

[3]. Hamalik, Oemar. 2006. Proses Belajar Mengajar. Jakarta: PT Bumi Aksara

[4]. Bektiarso,S.2000. Efektifitas Model CLIS Dalam Pembelajaran Fisika di SMU Dalam Jurnal Pancaran Pendidikan (no. 47 tahun XIII). Jember : Universitas Jember

[5]. Rustaman, Nuryani, dkk .2010. Materi dalam Pembelajaran IPA SD. Jakarta : Universitas Terbuka.

[6]. Kusumah, Wijaya dan Dwitagama, Dedi. 2012. Mengenal Penelitian Tindakan Kelas. Edisi Kedua. Jakarta: PT. Indeks.

[7]. Purwanto.2011. Evaluasi Hasil Belajar. Yogyakarta: PT Pustaka Belajar.

[8]. Dimyati dan Mudjiono.2006. Belajar dan Pembelajaran. Jakarta : Rineka Cipta.

[9]. Mukminan. (2013). Modul Pelatihan Pengembangan Keterampilan Dasar Teknik Instruksional. Yogyakarta: Universitas Negeri Yogyakarta

[10]. Wahyuningsih, D \& Murwani, S. 2015. Peningkatan Aktivitas Dan Hasil Belajar Siswa Pada Pembelajaran Biologi Melalui Implementasi Model Numbered Head Together Pada Siswa Kelas Xi Sma Negeri 2 Yogyakarta. Jurnal Pendidikan Matematika Dan Sains, 1: 65-71. 